\title{
Balkanologie
}

Revue d'études pluridisciplinaires

Vol. $15 n^{\circ} 2 \mid 2020$

Pour une approche socio-historique de l'action collective dans les Balkans

\section{The Chimera of Colorful Revolution in Macedonia: Collective Action in the European Periphery}

La chimère de la Révolution des couleurs en Macédoine: action collective à la périphérie de l'Europe

\section{Biljana Vankovska}

\section{(2) OpenEdition Journals}

Electronic version

URL: http://journals.openedition.org/balkanologie/2583

DOI: 10.4000/balkanologie.2583

ISSN: 1965-0582

\section{Publisher}

Association française d'études sur les Balkans (Afebalk)

\section{Electronic reference}

Biljana Vankovska, "The Chimera of Colorful Revolution in Macedonia: Collective Action in the European Periphery", Balkanologie [Online], Vol. 15 n² 2 | 2020, Online since 01 December 2020 connection on 22 April 2021. URL: http://journals.openedition.org/balkanologie/2583 ; DOI: https:// doi.org/10.4000/balkanologie.2583

This text was automatically generated on 22 April 2021.

(c) Tous droits réservés 


\section{The Chimera of Colorful Revolution in Macedonia: Collective Action in the European Periphery}

La chimère de la Révolution des couleurs en Macédoine: action collective à la périphérie de l'Europe

Biljana Vankovska

1 Macedonia, as a hardly known part of ex-Yugoslavia at the European periphery, has rarely made Western headlines except for the security problems too often associated with the region and the country's bizarre "name issue." ${ }^{1}$ Yet for a brief moment in 2014-2016, it seemed as if a sudden upsurge of social movements and popular protests would put it on the world map of countries experiencing collective actions and calls for radical social change. Many saw this upsurge as an encouraging development in a country burdened by democratic deficit and a hybrid illiberal regime, hoping that it could be part of a "Balkan Spring" (with similar events occurring in Croatia and BosniaHerzegovina). ${ }^{2}$ The developments became especially widely known because of the final act of the performance - the so-called Colorful Revolution (CR) of 2016 - when protesters used paintballs of diverse colors to shoot official buildings and monuments. However, the collective action stopped abruptly in mid-2016, as societal energy dried up like rain water in a desert.

2 This study sheds light on the reasons for and the context of the sudden surge and deflation of popular mobilization, as well as the general effects of the events as seen from the distance of five years' time. The text structure is determined by the predominantly socio-historical approach of the analysis: the first part sketches the historical context with special emphasis on the way Macedonia has been governed both internally and externally - since the breakup of Yugoslavia in 1991. Its aim is to present the main features of the political and institutional landscape before the phase of collective actions began in 2014. The second part focuses on the specific grassroots movement in which multiple plenums formed (plenumization), while the third part 
questions the very nature of the Colorful Revolution, its end and after-effects. The conclusion summarizes what the study reveals about collective action.

The main hypothesis is that in spite of the apparent authenticity and compliance with the key elements of a grassroots social movement which is still the dominant position in the academic literature on this case, ${ }^{3}$ the $\mathrm{CR}$ was more of a "template revolution" as conceptualized by Sussman and Krader, ${ }^{4}$ and similar to the "colored revolutions" in other post-socialist countries. ${ }^{5}$ In other words, the "protesters" employed an already existing template for fostering government change that also preserved the existing system for ethnic power-sharing and a neoliberal model of government. The study does recognize citizens' inherent need and ability to mobilize, but also underlines the limitations to the form of their mobilization that is set by a restrictive political model. This model, the template revolution, relies on elites bargaining and continuous international state-building interventions rather than on people's sovereignty.

4 From a methodological point of view, the study represents a combined explicatory and empirical analysis which draws mostly on primary sources such as public appeals, declarations and publications related to the events prior to and during the CR. It also draws on a number of semi-structured interviews with movement participants. For a researcher to be present on the scene as a participant-observer is both an asset and an obstacle. Such a study offers an insider's observation through an academic eye: few have opportunities to study the evolution of phenomena on the ground (in vivo) over many years. ${ }^{6}$ On the other hand, scholars who live within a designated context (and feel the effects of any action) are often considered biased, especially if their views do not conform to the prevailing political and academic narrative. The $\mathrm{CR}$ is still a dubious object of scholarly research, and local critical researchers risk being disqualified as partial and even anti-European. However, any scholar analyzes phenomena and draws conclusions from his or her own theoretical and grounded position. One of the most important challenges might be proving one's detachment and neutrality regarding the research object. As a scholar, I rely on the premises of critical theory as expressed by Robert Cox's dictum that "theory is always for someone and some purpose," and "there is no such thing as theory in itself, divorced from a standpoint in times and space." This dictum rings more true than ever in the post-Yugoslav and post-socialist context of the newly independent Macedonia after 1991.

\section{Setting the scene: uncharted territory of active citizenship and protests in Macedonian history}

5 For the major part of the international audience (including academia), Macedonia remains terra incognita, partly because of its peripheral nature to European and global affairs, but also because of a set of problems related to its existence that compromises full recognition of its sovereignty. These problems begin with the naming of the country and include the internationally-sanctioned questioning of the very existence of the Macedonian nation (as demos and ethnos), its language and history. However, these tensions should not be seen as a Balkan family problem because they involve much more powerful actors. Though ostensibly peripheral, Macedonia occupies a critical geopolitical position; it is a multipolar microcosm where global faultlines collide. ${ }^{8}$ 
6 The aim of this section is only to set the scene of the political and historical context of the collective action in 2014-2016. It cannot provide a complete country background, but even the briefest portrayal of the country consists of the following facts: Macedonia gained independence from socialist Yugoslavia in 1991 in a uniquely peaceful way, with not a single victim or bullet shot - therefore it was known as an "oasis of peace" - until the myth of (negative) peace shattered. It is a small country on the southern European periphery with approximately two million inhabitants, although we do not know a more accurate number because the 2011 census was never completed. ${ }^{9}$ It is alleged to contain an extraordinary ethnically mixed population that merits the name "Macedonian salad," but in reality the state is bi-national, shared by ethnic Macedonians (65\%) and ethnic Albanians (25\%) (according to the 2002 census). It is one of the economically poorest states in Europe (and may become worse in this time of pandemic).

\section{The post-socialist transition in the Macedonian "oasis of peace"}

7 Statehood and the right to self-determination of the Macedonian people are to be traced back to the formation of the Macedonian Socialist Republic as one of Yugoslavia's six constituent republics (1944). Generations of Macedonian citizens grew up with no awareness of dissidence. Tight security control and the network of informants prevented any such attempt, and many innocents were collateral damage of the disciplining exercises..$^{10}$ Even the 1968 student protests in Yugoslavia, remembered as something exceptional, did not echo much in Macedonia. However, the very same political context in which the socialist republic existed until 1991 has propelled different experiences, constitutional status and perceptions among the two major ethnic groups' national mythistory. ${ }^{11}$ For the ethnic Macedonians, the socialist republic and the recognition of the Macedonian language as one of the three official ones in the new federation was an emanation of a long-lived dream for statehood, while the ethnic Albanian history glorifies episodes of mass protests against discrimination and demands for the right of self-determination. Indeed, in Yugoslav constitutions, certain rights were recognized only for the Slavic "constituent nations" of the federation, not for the national minorities like the Yugoslav Albanians. Macedonia gained independence by a popular referendum held on 8 September 1991. The overwhelmingly positive result of the referendum was clouded only by the fact that the ethnic Albanians boycotted it. They did not want the status of minority in the new independent state. Nevertheless, the international community that was failing to avert the development of conflict everywhere in the war-thorn region of former Yugoslavia, saw the new republic as an "oasis of peace" and a "beacon of hope." In spite of such a rosy picture, an almost endless list of problems has accompanied Macedonia's statebuilding efforts since 1991. These include, to mention just a few, an extremely weak economic base, an almost non-existent state and lack of democratic traditions, an underdeveloped political culture as well as a dominant gun culture, and a turbulent geopolitical neighborhood. While Macedonia has handled all of these problems comparatively well, many issues remained undeniably unresolved.

8 The strong impact of ethno-nationalist violent conflicts in the region played an important role in determining the character of conflict prevention efforts in Macedonia. These paid overwhelming attention to the country's ethnic mix as an “explosive Macedonian salad." For a period of ten years (1991-2001), Macedonia hosted 
an array of international organizations whose projects focused on conflict prevention and resolution or inter-ethnic dialogue. These projects paid far more attention to the classic cliché of inter-ethnic relations than to more fundamental sources of potential conflict in the local society. Yet in spite of the name dispute with Greece and the obstacles on its way to full international recognition, Macedonia was just one more newly independent state engulfed by the latest wave of democratization.

With no critical discussion whatsoever, the country overnight joined a world already led the by TINA principle..$^{12}$ The dominant mantra was that political rights had priority over social and economic ones because it was held that personal welfare would follow automatically as democracy took root and the country joined NATO and the EU. Srećko Horvat and Igor Štiks give a good regional diagnosis that applies to Macedonia too:

In spite of the rhetoric of incompleteness, we can observe that the free market reigns supreme; post-socialist Eastern Europe is fully incorporated into the capitalist world in a semi-peripheral role. In practice this means the availability of cheap and highly educated labor in proximity to the capitalist core, a quasi-total economic dependence on the core and its multinational banks and corporations, and finally the accumulation of debt. On the political side, liberal democratic procedures formally seem to be there. ${ }^{13}$

Indeed, from the onset, the "primitive accumulation of capital" took a form of criminal privatization of what used to be in societal ownership. ${ }^{14}$ It gave birth to a new capitalist class, and created a lasting ground for new elites and a deep inequality gap, a consequence of the empty democratic façade of the capitalist transformation. The narrative of independence and statehood served as a sugar-coated pill for all those pushed into pauperization. ${ }^{15}$ To paraphrase Michael Pugh's diagnosis on Bosnia and Herzegovina, in Macedonia too ethno-kleptocracies rode a devastating economic transition with the assistance of foreign institutions. ${ }^{16}$

\section{Ethnic power sharing and international state-building}

11 After a while, the enthusiasm with political pluralism and electoral democracy faded away. The party landscape became quite simplified: once divided along ethnic lines, the two major ethnic communities formed bi-party systems each. The ethnic Macedonian side was reserved for two major parties: the Social Democratic Union of Macedonia (Socijal-demokratski sojuz na Makedonija, SDSM) (i.e. former communists), and the conservative Internal Macedonian Revolutionary Organization - Democratic Party of Macedonian National Unity (Vnatrešna makedonska revolucionerna organiyacija Demokratska partija na makedonsko nacionalno edinstvo, VMRO-DPMNE). The Albanian party scene was also dominated by two parties: Party for Democratic Prosperity (Partija za demokratski prosperitet, PDP) and Democratic Party of Albanians (Demokratska partija na Albancite, DPA). The electoral outcomes would eventually take a form of a bi-ethnic coalition, with clear domination of the Macedonian political party in the majoritarian parliamentary system (up to 2002).

The SDSM-led governments (1992-1994, 1994-1998) formed coalitions with the moderate Albanian party (PDP), but the willingness to meet Albanian demands was quite modest. The reaction came with the 1998 parliamentary election results that demonstrated electoral support for the more ethnically radical option promised by the DPA. The winning coalition of VMRO-DPMNE and DPA was not based on any consistent policy but there was a gradual move towards a more inclusive society, addressing 
ethnic grievances. Yet inter-ethnic understanding was a result of compromises involving the division of spheres of business and mafia interests between the two elite groups.

The 1999 NATO intervention over Kosovo affected strongly Macedonia's fragile interethnic balance. It became a turning point in the dynamics of the Macedonian conflict that escalated two years later and prompted the highest level of ethnic identification and homogenization among Macedonia's two largest ethnic groups since 1991. The appearance of the Albanian paramilitary National Liberation Army (NLA) and the violent outbreak came as a surprise even for the international observers. Officially, the conflict began in late February 2001 with sporadic shootings and clashes around remote and almost unknown villages on the Macedonia-Kosovo border.

The Ohrid Framework Agreement (OFA), signed on 13 August 2001, was meant to mark the end of armed conflict less than six months later. With the exception of the "Ten Days War" in Slovenia, the violent conflict in Macedonia was the shortest and most bloodless on the territory of former Yugoslavia. ${ }^{17}$ Again Macedonia became an international "success story," and ever since - an object of intensive international state-building. As in Bosnia and Herzegovina, ethnic differences were constitutionalized in a power-sharing model. The Dayton Agreement got a "twin brother": the OFA ${ }^{18}$ prescribed the same medicine for the divided Macedonian society although in a less complex (bi-national) form. ${ }^{19}$ The side-effects of the consociation model are all the same especially with regard to the societal relations and political culture that do not rest on free citizens' participation. The cartel of ethnic elites, decision-making based on double-majority rule and the quota system of recruitment only deepened already persistent partitocracy. The system often suffered deadlocks due to the perpetual ethnic bargaining, so the EU/US ambassadors or other international officials facilitated the process. Instead of producing institution-building and a democracy learning process, the outcome was the opposite: not only the political elites, but also the general public developed a dependency culture relying on the arbitrary power of international actors. ${ }^{20}$

On the eve of the first post-conflict elections in 2002, the former Albanian paramilitary transformed into a political party - the Democratic Union for Integration (Demokratska unija za integracija, DUI). Ever since, it has been a king-maker: no matter who was the winner on the "Macedonian" side of political spectrum, DUI was the most popular in the Albanian electorate. At a glance, it looked as if the power-sharing model contributed to overcoming inter-ethnic tensions and establishing peace and stability. Indeed, DUI proved to be quite skillful in terms of bargaining for ethnic demands with any coalition partner: its key priority in 2004 was the ethnic gerrymandering of the municipalities' borders while in coalition with SDSM, and then in gaining other ethnic concessions with VMRO-DPMNE (including the amnesty of crimes against humanity and war crimes where its members were charged or suspects). ${ }^{21}$

\section{Stabilitocracy as a side-effect of international state-building}

The coalition government of VMRO-DPMNE and DUI (2008-2016) worked perfectly well, at least on the elite level. The international mentors were not always satisfied with the policies and succession of crises, ${ }^{22}$ but they turned blind eyes to these for the sake of inter-ethnic peace and intervened when necessary. 
17 At the 2008 NATO summit Greece vetoed Macedonia's membership bid. This represented a political turning point, especially for Prime Minister Nikola Gruevski, the leader of VMRO-DPMNE. He took advantage of the great disappointment about international recognition in order to strengthen his semi-autocratic rule. Later on Macedonia would be dubbed a "captured state" in EU country reports, but throughout the years of Gruevski's rule, the European Commission gave generally positive country reports and regularly recommended that accession talks between Macedonia and the EU should begin. As long as Gruevski looked loyal to Western power centers and promised ethnic peace and a solution to the name dispute with Greece, he was tolerated by Brussels.

In other words, Macedonia functioned as a stabilitocracy. As aptly described by Srdja Pavlović who coined the term:

The core value of stabilitocracy is a conviction that protecting and promoting Western interests is paramount.... Regimes which understand that core conviction and are willing to protect and sustain Western geopolitical, security, military, economic or energy-related interests in a given country are usually spared the wrath of the great powers such as the United States, the UK, or the European Union. Local autocrats, therefore, can do whatever suits their needs in their private domains. Any criticism directed towards them is usually dismissed as either sour grapes from a political loser or an attempt by retrograde undemocratic political forces to gain the upper hand. ${ }^{23}$

Ironically, the Gruevski-style populism that developed over time was a "child" of the unsuccessful international state-building and failed promises of NATO and EU. Gruevski's tenacious rejection to accept external pressures to change the country's name (and especially, his unexpected move to litigate Greece before the International Court of Justice $)^{24}$ made him less desirable as a Western partner. Seen previously as a non-charismatic, technocratic leader with some economic skills and readiness to accept all neoliberal medicines, all of a sudden Gruevski turned into a national leader and hero, at least for the vast majority of ethnic Macedonians. Identity politics carried out through the "Skopje 2014 " 25 project strengthened his political rule on nationalist grounds. This project consisted of the construction of colleges, museums and government buildings, as well as the erection of monuments depicting historical figures (most significantly, a monument of Alexander the Great in the main city square). The project became, however, highly controversial in ethnic, political and financial terms. It would become a feature of special significance for the 2016 Colorful Revolution, as we will see later.

\section{The occurrence: plenumization and its limits}

The citizens' discontent had never been a secret but it never produced alarm: it was hardly articulated and not well organized. Yet during the VMRO-DPMNE/DUI government, small protests gradually became more frequent. ${ }^{26}$ Citizens protested over a number of issues, such as "Skopje 2014," electricity prices, police brutality, etc. In some instances, ethnically motivated protests turned violent but remained limited (if polarizing) in their effects. The 2012 "March for Peace" was a one-off event that tried to bring together people from different ethnic and political groups in order to call for peaceful co-existence. The issues and activities related to the LGBT community, 
women's movement and sexual workers gained visibility due to the external support of local NGOs.

The inflation of activism would usually bring together the same flock of people: NGO activists and intellectuals promoted various agendas and spoke on behalf of different interest groups. They were usually well-trained, well-spoken and financially sustained by foreign donors. ${ }^{27}$ The protests were ill-attended or seen as a mere spectacle. Having been faced with its impotence, the political opposition transformed itself into a "nongovernmental entity." ${ }^{28}$ VMRO-DPMNE invented "counter-protests." ${ }^{29}$ The NGO sector was also deeply divided along political lines, so each party could rely on its "own people" and civil society organizations. A 2014 survey showed that as many as $73.4 \%$ of the respondents did not believe in the spontaneity of protests. ${ }^{30}$ As such, the political parties had usurped not only the public space but also any form of civic engagement.

The Slovenian sociologist Rastko Mocnik rightly points to systemic disempowerment all over the region.

Protests are a complex matter. If people truly live in deep poverty, they can hardly attend protests because they have to work in order to survive. If however there is a significantly large group with no other choice, then it turns into a huge problem and protests are not enough. ${ }^{31}$

People gradually adjusted to structural violence and even developed skills to find a way to bypass the institutions through illegal means, social connections and corruption.

\section{Plenumization 2014/2015 - a new experience}

24 In that context, the 2014/2015 student protests erupted as a very surprising and powerful collective action. Nobody could anticipate the reaction to the revision of the Law on Higher Education that effectively curbed university autonomy..$^{32}$ At first, satirical media mocked the students' passivity. ${ }^{33}$ The campaign started shyly in October 2014 but swiftly grew into a mass movement. The students eventually self-organized into the Student Plenum (SP), clearly taking inspiration from similar forms of activism in the region (mainly Croatia).

Their first public appearance took place on International Student Day, 17 November. It was met by disbelief even by the organizers: over 3,000 students joined the street march. The second one took place on 10 December (International Human Rights Day) and was even more impressive with over 10,000 protesters. The students echoed some well-known slogans: "No justice, no peace" and "It was enough silence." ${ }^{34}$ The public called upon the students to take over the leadership because the adults had failed to build a democratic state. When it was no longer possible to ignore them, the government argued that the students were manipulated by the opposition or were provocateurs financed by external powers in order to incite a Macedonian Euromaidan, ${ }^{35}$ referring to the 2014 Ukrainian crisis that had been assimilated to a colored revolution. ${ }^{36}$ The student leaders appealed to the political parties to stay out of their actions:

our demands go beyond any party related affiliations. As an important societal actor, as students, we continuously insist on our intellectual independence, our free and critical thought, which is not directed by any populist agenda and is a consequence of Reason.... Authenticity of the Plenum is invaluable, and all sides are going to understand this sooner or later. The Piedmont of the Student Plenum are the arguments that are not directed against the political parties but against injustice. $^{37}$ 
26

SDSM exposed a wiretapping scandal (allegedly gained from whistle-blowers) and released audio recordings, the so-called political bombshells, under a campaign called "The Truth about Macedonia." Social unrest was simultaneously growing due to another reform of taxation law that stipulated that the precarious workers in general would have to deduct up to $40 \%$ of received honoraria as tax for the state budget. The same period witnessed mass protests against the prosecution of journalist Tomislav Kežarovski, who was charged with revealing the identity of a protected witness in an article published in $2008 .{ }^{45}$ Faced with simultaneous challenges, the government took a step back and started bargaining with concessions to each of the discontent groups. As far as the protests of students and professors were concerned, the olive branch was offered by the prime minister himself: the law was suspended just days upon its adoption in the parliament and working groups that included professors and students from both plenums were invited to draft a new law.

30 It seemed as if plenumization had taken root. It became fashionable to follow the students' example, so journalists, pupils, parents, and other groups formed plenums. Few really knew what the plenums meant at first. It was a new phenomenon and it looked like a straightforward victory for active citizenship. Yet mass plenumization 
(which would follow Bosnian experiences) soon failed; or rather, it was abandoned for the sake of other forms of protest.

31 Plenumization had shown its weaknesses quite early. First of all, the number of engaged students was not as large as perceived in relation to the total size of the student population. The constant re-negotiations among equals with different opinions made the decision-making too slow, especially in a dynamic situation that called for swift responses. The plenum activists did not have time to articulate a clear agenda and final goal. The winter break at the university diminished the power of the movement, so the protests were on hold. The internal split happened de facto when the students had to make up their minds over the government concessions (i.e. the offer to make working groups that would involve all stake-holders in order to address the grievances). For the radical segments in the movement any negotiation was seen as a sign of weakness and even as "collaboration with the enemy." Occupation of the university took place exactly at the moment when the negotiations gave concrete results and a working group was formed to propose a new law. A symbolic "free zone" was declared only at the Faculty of Philosophy. The students - already the public's darlings - appealed for help in food donations just days after the aid campaign for the victims of the flooded areas. They were obviously not under siege: one could go home, take bath or a meal, and then get back to the "liberated" university. The majority of students were regularly attending classes and bypassing the protesters. ${ }^{46}$ In contrast, the number of attendees who were not students but rather public personalities was rising. The student mobilization had reached its limit within a fortnight. Yet the autonomous zone was a unique experience, which gave a symbolic feeling of ownership over the otherwise alienated educational process.

The PP manifested the same weaknesses. The core group also insisted on the horizontal organization and on a decision-making process in vivo. At its peak, the PP embraced over 500 professors (at least that was the number of signatories of the Open Letter); in reality, only a handful of the most eager participants attended the meetings and made decisions on behalf of all the others with no prior consultation. Hence all those who were too busy, too old, or too far from Skopje to attend were outcast. The PP was also supposed to be leaderless and non-partisan; in reality, many of the professors were political "have-beens" and some were still-active politicians. But it was indeed something new because for the first time ever the academic staff joined over a concrete academic and vocational interest against other political differences.

PP also came into crisis at the moment it was expected to be the most efficient. The professors with qualifications in law and education were the ones who negotiated with the governmental officials - and risked being accused of treason by others in the plenum. Throughout the most dramatic period, most energy was wasted on social media and excessive email communication. Not a simple draft of a new law had been produced even when the government agreed to cooperation; few knew how to draft a law or what model would fit the best.

The appearance of the PP on the scene at first was met with appreciation by many, including the SP. It was supposed to be a joint struggle, but in reality it was perceived differently by the stake-holders. Each side had its own legitimate interests. Coordination at times was impossible. The students could undertake guerrilla actions or performances that were not suitable for the professors, and vice versa. The public had divergent attitudes towards the plenums. Free from any baggage, the students were 
seen as heroes; the professors on the other hand became a burden or even a rival. The students' inclusion in the process of negotiation was a hard task because the students could not come to a unified position within their own diverse plenums (at each faculty). In sum, both plenums had been coping with their own identity and goals, let alone age and interest divergences. The time pressure (i.e. the law had already been in procedure) did not allow any meaningful deliberation.

The professors and students won a partial victory over the legislation but failed to deliver any draft law or to develop any lasting forms of deliberation within their communities, let alone joint ones. The months of turbulence prepared them for the looming political drama. Unlike Bosnia and Herzegovina where the plenums had a social substrate of mobilized workers and poor citizens, the Macedonian ones with their narrow focus on the higher education were rather elitist. ${ }^{47}$ It was only in the following stage that the protesters widened their approach. Yet unlike the Bosnian plenums that distanced themselves both from the political parties and NGOs, the protest movement in Macedonia was led by NGO activists and blessed by the international community.

\section{Friends and foes: protest movement(s) and political parties}

The ongoing political crisis escalated on 5 May 2015. It overshadowed the student protests and amalgamated them. The trigger was the audio "bombshell" released by SDSM leader Zaev that exposed a phone call between the Minister of Interior and her aide over the death of young Martin Neškovski. ${ }^{48}$ The same tragic episode had already been a trigger for 2011 protests against police brutality; four years later it was still a highly emotional and politically mobilizing issue. ${ }^{49}$

On 5 May 2015, a violent clash occurred between the protesters and the police. It was a turning point: the political cause (regime change) overshadowed all the others. ${ }^{50}$ It also helped set the scene for an allegedly Manichean battle. Each of the two blocks solidified their rows: the pro-government side got the "ultimate proof" that the opposition had been fabricating Euromaidan, while the opposition "proved" that the regime was a fascist one not to be negotiated with on moral grounds. Any voice of reason or impartiality was condemned by both sides. ${ }^{51}$

The umbrella protest movement "I Protest" (\#Protestiram) was proclaimed on 10 May 2015 as a fusion of all existing movements and initiatives over various issues - and over the years before it had existed. ${ }^{52}$ While it was hardly known who initiated it or how it was made, \#Protestiram was said to be a citizens' plenum. Its demands were the following: urgent resignation of the government; urgent release of all activists detained after the 5 May protests, and formation of a caretaker government. ${ }^{53}$ The student activists put their original struggle for a new law on higher education under moratorium with a justification that it was immoral to negotiate with an authoritarian regime. For a couple of months there were everyday protests in front of the government or other institutions, marches and speeches, and traffic blockades.

On its side, SDSM had a clear strategy: the "bombshells" were streamed every day in order to stir up public rage over the allegations for numerous crimes committed by government officials, and to eventually enforce the government's resignation. For that purpose, one more popular front was created on 8 May 2015: Citizens for Macedonia brought together a long list of 80 well-established NGOs and well-known activists and 
intellectuals. The charter was presented by Stevo Pendarovski, professor and long standing supporter of SDSM, who would later become President of the Republic in 2019. Citizens for Macedonia overtly declared a coalition with the largest opposition party (SDSM).$^{54} \mathrm{~A}$ mass rally under the slogan "We are coming" took place on 17 May in front of the government building. It was no secret that the logistics, transportation and everything else was provided by SDSM. It was known that Zaev faced a logistics problem in gathering the "biggest protest in the country's history," and because he could not provide enough buses, he had to import some from Bulgaria. ${ }^{55}$ The scenario of the event was indicative: the first speakers were two representatives of the SP (a Macedonian boy and an Albanian girl, which was meant to break the gender and ethnic stereotypes), followed by a few NGO activists and intellectuals close to SDSM; the visible absence of partisan symbols, and the knotted Macedonian and Albanian flags created a mirage not only of a non-partisan gathering, but more importantly of a bi-ethnic one. The presence of ex-foreign ambassadors and European MPs sent a message of international support. The key event, however, was Zaev's speech, after which the socalled Freedom Camp was set up. This was basically a Potemkin village of tents erected in front of the government building. They blocked the main traffic artery until the end of the already- started party negotiations with international mediators. The camp resembled the "occupation of the university" both vis-à-vis its daily agenda and the fact that few of its occupants stayed overnight. Eventually, everything turned into a big spectacle: the "Citizens" were partying during the warm summer nights, and the revolution ended up in a karaoke-show with the protesters singing "The Government is Falling." ${ }^{56}$

In parallel, VMRO-DPMNE remained loyal to its habits and organized an equally large gathering including a counter-camp in front of the parliament building just a day after the first one was established. ${ }^{57}$ The scenography was nationalistic, in accordance to Gruevski's message that Zaev intended to take over the government in order to change the country's name.

41 At first glance, it looked as if the various fronts resisting the government differed only in their methods of fighting. Citizens for Macedonia preferred debates with professional NGO activists and politicians in the Freedom Camp, while \#Protestiram insisted on street blockades, marches, and art performances. Citizens for Macedonia used mainstream neoliberal phraseology, though contentious symbols were displayed all over the camp..$^{58}$ \#Protestiram tried to appeal to ordinary people, occasionally even challenging the neoliberal dogma.

There was, however, an important difference. The traditional political opposition had reformulated itself as a nation-wide anti-government movement in the form of Citizens for Macedonia. A few small sections from the earlier-formed movements tried to distance themselves on this point. A student explained explicitly that the SP had joined the 17 May rally only on the condition that a clear distinction was made: it was not a part of Citizens for Macedonia or any party. ${ }^{59}$ Some activists from \#Protestiram argued that the coalition of opposition parties and NGOs had suffocated the pluralism among the resistance forces: "after 17 May the resistance entered a deep crisis. The protests deflated and the awaited turnaround did not happen." the politics of passion and to mobilize more people - but in vain. With the appearance of Citizens for Macedonia, high politics took priority in a typical negotiation process where international state-builders preferred to deal with party leaders. 
As in all of Macedonia's preceding critical moments, the representatives of NATO, the $\mathrm{EU}$ and the US were involved in the mediation process, as were the representatives of the four main political parties (VMRO-DPMNE, SDSM, DUI and DPA). The end result of a two-week-long series of discussions (2 June-15 July 2015) was the so-called Pržino Agreement. ${ }^{61}$ Officially, it marked the end of the first part of the political crisis. It foresaw participation of SDSM in a few key ministries; early resignation of Gruevski by January 2016; a caretaker government to bring the country to parliamentary elections; and the installation of a Special Prosecutor to lead investigations into the crimes highlighted by the wiretapping scandal. ${ }^{62} \mathrm{~A}$ day after the agreement's conclusion, Zaev met with the representatives of the coalition Citizens for Macedonia. The Freedom Camp was dissolved and the "Citizens" dispersed. The international mediators felt more comfortable with politicians they could control; new ideas that may have led to a Macedonian "SYRIZA/Podemos" were met with reserve. ${ }^{63}$ According to \#Protestiram, the inter-party political solution mediated by the internationals terminated the very idea of protests and resistance. ${ }^{64}$

However, a self-critical analysis claims that the movement was an ideologically incoherent body, and the bone of contest was how close or far the activists were from the political opposition.

The main disadvantage of the movement was in the fundamental unsustainability of the idea of burying all differences until the fall of the regime. It became evident that the differences were substantial and ideological. While some showed strong liberal and anti-authoritarian tendencies, the pro-SDSM group acted in quite an authoritarian fashion. The constant insistence on a complete and blind support of the SDSM leadership, the "you are either with us or against us" logic, and the demonization of everyone who did not give their wholehearted support to SDSM with the derogatory "neutrals" only went to show the authoritarian tendencies in the ranks of the pro-SDSM wing of the resistance..$^{65}$

Having been caught into an exhausting political soap opera, the public got confused, tired and eventually bored by the tents, camps, marches and street blockades. The "clicktivism" eventually became the main form of activism: the silent majority preferred debating or fighting on internet social networks. ${ }^{66}$

The period between the Pržino closure of the political crisis in 2016 and the outbreak of the CR in 2016 was de facto in limbo. The protest coalitions were disbanded, and activists only occasionally appeared on the scene to remind the political parties that they should follow the agreement created under the auspices of the international factors.

\section{Colorful revolution: a "colored revolution" as usual?}

As already seen, Macedonia witnessed a fast transformation from one form of dissent into another in a compressed two years' period. Apparently, there was an aggregation of a range of erratic forms of collective action. If the original outbreaks of protest in 2014 might be compared to similar processes that had taken place previously in Bosnia and Herzegovina (with a clear social background), and even Croatia (with student protests), the 2016 events bore clear resemblance with already seen colored revolutions from Eastern Europe (such as Serbia in 2000, Georgia in 2003, Ukraine in 2004, and again in 2014). David Lane enlists the elements of the phenomenon in the following way: 
The activities given the popular appellation of "coloured revolutions" all had in common a proposed socio-political transformation intended to introduce "democracy from below". Although differing in content, they shared a common strategy: mass protests occurred within the constitutional framework to widen forms of public participation in the regimes: they were legitimated as a movement for "greater democracy": they were all targeted on removing the incumbent political leaderships; electoral procedures, allegedly fraudulent, were a regular focus for the insurgents; the public gatherings were constituted from a mass base of young people, particularly students. ${ }^{67}$ greatest media coverage abroad but the daily marches failed again to mobilize the silent majority. A 2016 survey of the Institute for Democracy displayed that citizens were divided over their support for the protest movements, practically reflecting the key political division between the two major political parties. Fewer than half of respondents (46\%) supported the protests, and $62 \%$ from within the $46 \%$ were in favor of the CR, while $25 \%$ were supporting the VMRO-DPMNE camp..$^{69}$ The "usual suspects" (i.e. well-known NGO activists and intellectuals from other anti-government events) were leading the walks (with expensive bicycles and fancy pets) and taking part in the public debates. The performances were "colorful" only visually, while in essence they were routines that would take place for a couple of hours each afternoon on working days, with breaks during weekends and holidays.

51 At first sight, the CR (Šarena revolucija in Macedonian) was unexpected and spontaneous. Yet insightful analysis displays a different story. The chosen name ${ }^{70}$ was supposed to be both descriptive and functional: it served to acquire the aura of a heroic popular revolution against a corrupted and dictatorial regime. The buildings of "Skopje 2014" that were targeted with paintballs not only symbolized the power structures, but also the VMRO-DPMNE and DUI identity politics attached to the project. Unlike other colored revolutions, which opted for one color (or symbol) as their signifier, in this case the mixture of colors was supposed to symbolize the diverse coalition of a multi-ethnic and multi-confessional society (i.e. "Macedonian salad"). The message could be read as 
follows: Gruevski is a hardline nationalist, and we are all united against him, despite our diversities, to create a new civic democracy, one society for all, with a clear proWestern orientation.

Similarities with the other colored revolutions were evident in many respects. First of all, the repertoire of methods and actions (protest marches, student activism, guerrilla actions, art performances) all come under the umbrella of nonviolent resistance. Second, the practical and educational inspiration came from the well-known apostles of civil resistance, such as Gene Sharp and Saul Alinsky. ${ }^{71}$ Third, the avant-garde of the movement were notable NGO activists, the leaders of the student movement, a part of the intellectual and cultural elite, ex-politicians and journalists. De facto NGO-ization of the resistance took place. ${ }^{72}$ Fourth, there was a visible use of a so-called marketing wing. ${ }^{73}$ The hallmark of other colored revolutions was in full use: the name, the paintballs, the logo of a black-and-white clenched fist, sprays, a plethora of promotional gadgets such as T-shirts, printed stickers, flyers, banners, websites mushrooming for a while and use of social media, irony and street events mocking the regime have been hugely successful in puncturing public fear and enraging the powerful. ${ }^{74}$ The commercial-type of language was deemed to be more receptive than ideological language. ${ }^{75}$

The notion of an interrelated wave of colored revolutions is, furthermore, of specific importance in this case. ${ }^{76}$ The Colorful Revolution occurred, inter alia, because of transnational ties, learning processes and the power of example. ${ }^{77}$ Some of the participants of the $\mathrm{CR}$ have spoken privately of external involvement. ${ }^{78} \mathrm{Chris}$ Deliso, an American expert on the Balkans, argues that such protest movements in Macedonia are not endemic, and would simply evaporate without foreign funds. ${ }^{79}$ The media helped to create the image of mass and unpaid spontaneity, although Western assistance programs were pouring money into the spectacle. As already noted, a number of websites, initiatives and performances, including TV shows, were financed during this critical period. As soon as the political crisis calmed down, they simply vanished from the public space..$^{80}$

54 If it is generally true that "regime collapses have resulted more from authoritarian weakness than opposition strength," ${ }^{81}$ the very manifestation of the CR should be seen as due to the inherent weakness of the regime. Indeed, Gruevski was a paper tiger caught in flagranti with the wiretapping scandal and under the simultaneous pressure of political opposition, international power centers and the public. However, unlike many autocrats overthrown through colored revolutions, he could still rely on significant popular support that did not rest only on propaganda and dependency, but also on a genuine belief among citizens that he was the "defender of national interests." More precisely, he was seen as someone who stood against all pressures from abroad to change the name Macedonia for the sake of NATO and EU membership.

Vicken Cheterian ${ }^{82}$ argues that the colored revolutions have been usually elite-led although they have depended on popular mobilization to bring about regime change. The CR aftermath showed that the activists failed to bring popular mobilization, which was proved not only on the 2016 December parliamentary elections but even more on the 2020 early elections. ${ }^{83}$ In spite of everything, in 2016 VMRO-DPMNE won the biggest number of seats, though not enough to form a government. The regime change took place due to its lost capacity for coalition-building; DUI got a better offer and switched sides. Thus de facto just one part of the past regime was ousted through a political and 
electoral "revolution": while the major conservative party (from the Macedonian block) was replaced by SDSM, the second half of the coalition, the Albanian party DUI, has remained a king-maker to-date. DUI had been a loyal partner of VMRO-DPMNE since 2008 but few dared to call for its political or even legal responsibility.

Despite the huge disillusionment with the new government and the new scandals ${ }^{84}$ that involved precisely the institutions that were expected to bring justice and peace (as the slogan of the $\mathrm{CR}$ read) not only has any meaningful critical debate been missing but also any (even the weakest) sign of collective action. After the CR and the regime change, the country seemed to be back to square one: a new regime was installed in 2017 - with the same deficiencies, democratic deficit and dearth as the old one - but with no real power for dissent. The only change brought by the new government has been the new name - the Republic of North Macedonia - and NATO membership (as of March 2020). These decisions have been taken against the will of the majority of citizens, as expressed by the referendum on the name change held on 30 September $2018 .{ }^{85}$ Judging from the results, it seems as if the whole undertaking was meant precisely to achieve this change and can be explained only by geopolitical reasons: the removal of the previous uncooperative government was a must. ${ }^{86}$ The shock therapy and the systematic disempowerment of the citizens was best illustrated during the 2017/2019 period when the people failed to protest against the national engineering imposed by the EU over the change of the country's name, identity, history and constitution.

The political U-turn was finished, and Macedonia (now renamed as North Macedonia) has returned to square one, debating its history, identity and inter-ethnic issues. The real effects of the progressive protest movements (2014/2016) can be seen only in a simple regime change. As a young scholar and participant of \#Protestiram noted: "Gruevism" was simply replaced by "Zaevism," and basically the political status quo was preserved. ${ }^{87}$

58 Today's society in Macedonia has been going through an anti-climax when it comes to political, electoral or social change. The disappointment has gone deeper after the leak of four short audio tapes of Zoran Zaev, in which he is heard swearing about the people on the eve of 2016 elections and boasting that the protest groups, "all of those Soros funded groups, they are mine." 88

\section{Conclusion}

Despite the fact that the analyzed protest movements have proved to be just a temporary episode, the article stresses the importance of the wider historical and political (including the geopolitical) context on the possibilities of a grassroots influence on the system. Yet the very fact that society experienced something that looked like a political or societal "spring" is important.

The CR had been envisaged and encouraged by external factors who took advantage of the frustrations and potential for protest that had existed especially among the younger generation and intellectual elite. This is in contrast with the attitude towards the protests in Bosnia and Herzegovina. In the latter case, preservation of the Dayton status quo and neocolonial status of Bosnia and Herzegovina have had priority over any demands coming from a grassroots movement. In Macedonia, a political change (i.e. simple regime change) was of utmost importance both because of the decay of the system and the need to speed up the process of the country's geopolitical integration 
through NATO. It is important to note that throughout the analyzed period, the Albanian political parties took part only symbolically in the protests or behind the scene. The power-sharing system is a limiting factor to joint mobilization. The activists tried to create an image of a non-ethnic (or even all-ethnic) movement in contrast to the alleged mono-ethnic support for VMRO-DPMNE. They, however, thus disregarded the responsibility of DUI for everything that had been done during their common rule over a decade. The protests are just the most visible part of a socio-historical event, and often do not express even the deepest grievances.

Few pay attention to the factors that systematically disempower the citizens' participation in political life. One of them is surely that within the neoliberal context, the voters can only choose between Coca-Cola and Pepsi Cola (to paraphrase Chantal Mouffe). ${ }^{89}$ In the power-sharing system the only choice is even more limited.

The citizens in their semi-protectorates are certainly never encouraged by international state-builders to take active participation that goes beyond party-politics. ${ }^{90}$ Within the existing public space, and for the sake of internal strife for power, the political parties have always been treated as the only capable actors for mobilizing their own membership (using stick and carrots) and occasionally the citizens, by providing the logistics for any mass rally. The greatest achievement of the student protests was precisely overcoming, at least temporarily, a barrier of distrust concerning the potential for political leadership with the majority of citizens. Zaev's rule, however, has deepened the original distrust, while new generations of students do not remember the SP protests and live and study under worse conditions than before.

If resistance is understood as an endeavor that undermines dominance as well as hierarchical relationships then no resistance has taken place yet in Macedonia. The government has changed but only within the dominant framework of a "holy alliance" among internal and external political elites, market "forces" and privileged civil society actors. The internal forces that may want to challenge the established order face not one, but two opponents. If the citizens of the EU periphery can hardly take their destiny in their own hands - which was displayed in Greece with the experience of the SYRIZA-rule - then obviously states such as Macedonia belong to the superperiphery.

The CR was therefore less a "social revolution" than a "political revolution." At the end of the day, citizens had to make "Hobson's choice" by accepting Zaev's government and everything that goes with it. Lack of sufficient internal potential and resources for deeper change further compromised by the guiding effects and impact of geopolitical interests in the European periphery were key determinants. These problems are here to stay as long as this equilibrium persists and sustains elitist positions with regard to both neoliberal ideology and an ethnicized view of politics. 


\section{NOTES}

1. Ever since 1991 when it gained independence from Federal Yugoslavia, Macedonia was forced to deal with a unique and unprecedented problem in the history of international relations over its right of self-naming and self-determination. Greece argued that the name Macedonia implied Skopje's irredentist aspirations [to annex Greek territory], and both the EU and UN agreed that the situation posed a security problem. The solution was found in imposing the official name of the Former Yugoslav Republic of Macedonia to the country before it could gain admission to the UN. In 2019, the country was renamed North Macedonia. This article deals with developments prior to that. For the sake of clarity, I use the simpler names of the Republic of Macedonia and Macedonia. For more on the name dispute see: DZUVALEKOVSKA CASULE Mircela et al. (eds), The Name Issue Revisited. An Anthology of Academic Articles, Skopje, MIC, 2012; SKARIC Svetomir et al. (eds), The Name Issue - Greece and Macedonia, Skopje, Matica Makedonska, 2009.

2. BIEBER Florian, BRENTIN Dario, Social Movements in the Balkans. Rebellion and Protest from Maribor to Taksim, London and New York, Routledge, 2018.

3. See RIZANKovsKa Josipa, tRAJKosKa Jasmina, "A Social Movement in First Person Singular: The Colours of the 'Colourful Revolution' in North Macedonia," Southeastern Europe, vol. 43, $\mathrm{n}^{\circ}$ 1, 2019, p. 1-27; REEF Paul, "Macedonia's Colourful Revolution and the Elections of 2016. A Chance for Democracy, or All for Nothing?," Südosteuropa, vol. 65, n 1, 2017, p. 170-182. Another author gives more credit to the international community. See: STEFANOVSKI Ivan, "The Impact of Social Movements on Policy Outcomes in Partly Free Democracies: Evidence from the "Citizens for Macedonia' Struggles in a Captured Macedonian State," East European Politics and Societies: and Cultures, vol. 20, $\mathrm{n}^{\circ}$ 10, May 2020, online: https://journals.sagepub.com/doi/full/ 10.1177/0888325419897999 (accessed in November 2020).

4. S USSMAN Gerald, KRADER Sascha, "Template Revolutions: Marketing U.S. Regime Change in Eastern Europe," Westminster Papers in Communication and Culture, vol. 5, n 3, 2008, p. 91-112.

5. LANE David, “'Coloured Revolution' as a Political Phenomenon," Journal of Communist Studies and Transition Politics, vol. 25, n² 2-3, 2009, p. 113-135; CHETERIAN Vicken, "From Reform and Transition to “Coloured Revolutions,"' Journal of Communist Studies and Transition Politics, vol. 25, $\mathrm{n}^{\circ}$ 2-3, 2009, p. 136-160.

6. I have been continuously engaged in a number of intellectual initiatives, petitions and protest movements since 2004. In this article, however, I refer mostly to the events related to the Student Plenum, when a group of students approached me with a request to help them mobilize the professors in their support. I was one of the founders of the Professor Plenum, but I distanced myself at the moment of political/party infiltration.

7. Cox Robert, "Social Forces, States and World Orders: Beyond International Relations Theory," Millennium, vol. 10, n² 1981, p. 126-155 (128).

8. FOUSKAS Vassilis, GOKAY Bulent, The Disintegration of Euro-Atlanticism and New Authoritarianism, London, Palgrave, 2019.

9. DASKALOVSKI Zhidas, "Census Taking and Inter-ethnic Relations in Macedonia," Southeast European and Black Sea Studies, vol. 13, n 3, 2013, p. 365-379.

10. котеSKA Jasna, Communist Intimacy, Washington, D.C., New Academia Publishing, 2014.

11. The term was coined by William Hardy McNeill, former president of the American Historical Association (AHA). See: McNeILl william Hardy, "Mythistory, or Truth, Myth, History, and Historians," American Historical Review, vol. 91, nº 1 (February), 1986, p. 1-10.

12. Acronym for "There Is No Alternative," uttered by Margaret Thatcher in the 1980s in support of neoliberalism. 
13. HORVAT Srećko, ŠTIKS Igor, Welcome to the Desert of Post-Socialism: Radical Politics after Yugoslavia, London and New York, Verso, 2015.

14. SHAJNOSKI Slobodan, "Privatization and Organized Crime in Macedonia," European Journal on Criminal Policy and Research, vol. 22, $\mathrm{n}^{\circ} 4,2015$, p. 655-668.

15. PUноvsкi Žarko, “Democracija i kapitalizam," Peščanik, 24 December 2012, online: https:// pescanik.net/demokracija-i-kapitalizam/ (accessed in May 2019).

16. PUGH Michael, "Corporate Peace: Crisis in Economic Peacebuilding," in Tobias Diebel et al. (eds), Rethinking Paradigms and Practices of Transnational Cooperation, Abingdon, Routledge, 2016.

17. About the 2001 conflict see: VANKOVsKa Biljana, Current Perspectives on Macedonia: The Struggle for Peace, Democracy and Security, series I-IV, Berlin, Heinrich Böll Stiftung, 2002; HISLOPE Robert, "Organized Crime in a Disorganised State: How Corruption Contributed to Macedonia's MiniWar," Problems of Post-Communism, vol. 49, n 3, p. 33-41.

18. The Ohrid Framework Agreement, online: https://www.osce.org/skopje/100622 (accessed in May 2020).

19. NIKOLOVSKA Natalija, SILJANOvSKA-DAVKovA Gordana, Macedonian Transition in Deficiency from an Unitarian to a Bi-National State, Skopje, Magor, 2001.

20. MCENVoy Joanne, Power-Sharing Executives. Governing in Bosnia, Macedonia, and Northern Ireland, Philadelphia, University of Pennsylvania Press, 2015.

21. "Macedonia: Time to Deliver Justice to the Victims of War Crimes," Amnesty International press release, 1 September 2011, online: https://www.amnesty.org/en/press-releases/2011/09/ macedonia-time-deliver-justice-victims-war-crimes/ (accessed in May 2020).

22. The deep crisis over approval of the 2013 national budget culminated in an attempt to prevent the parliamentary session by the SDSM representatives, who were eventually forcibly ejected during the vote along with attending journalists. The crisis spilled over to the streets where two party armies were separated by the special police forces. Then SDSM leader Branko Crvenkovski (a former Prime Minister and President of the Republic) called for mass civil disobedience. The activities were soon transferred to another allegedly non-partisan movement, Otpor (Resistance), that did not hide its inspiration from the Serbian revolution. "Black Monday," as these events came to be known, exacerbated the already difficult relationship between the two major Macedonian parties, while the Albanian ones remained passive observers. The crisis paralyzed the government in 2013 until the EU got involved and negotiated an inter-party deal over forthcoming local elections. GROZDANOvSKA DIMISHKOVSKA Ljubica, Nations in Transit 2014: Macedonia, Freedom House Report, online: https://freedomhouse.org/sites/default/files/ 17.\%20NIT14_Macedonia_final.pdf (accessed in May 2020).

23. PAVlović Srdja, "West is Best: How 'Stabilitocracy' Undermines Democracy Building in the Balkans,” LSE Blog, 2017, online: https://blogs.lse.ac.uk/europpblog/2017/05/05/west-is-besthow-stabilitocracy-undermines-democracy-building-in-the-balkans/ (accessed in May 2020).

24. ICJ ruled that Greece had breached its obligations under the 1995 Interim Accord when it objected to the NATO candidacy of Macedonia at the Bucharest summit. While the legal decision had no effect whatsoever on Greece, NATO or the EU, it had strong internal effects on the Macedonian electorate. See: "Greece Breached Accord with Former Yugoslav Republic of Macedonia - UN court,” UN News, 5 December 2011, online: https://news.un.org/en/story/ 2011/12/397222-greece-breached-accord-former-yugoslav-republic-macedonia-un-court (accessed in May 2020).

25. On "Skopje 2014" see more in: KOTESKA Jasna, “Troubles with History: Skopje 2014," Artmargins Online, 29 December 2011, online: https://artmargins.com/troubles-with-history-skopje-2014/ (accessed in May 2020); cHAUSIDIS Nikos, Proektot Skopje 2014 - Skici za edno naredno istražuvanje, Skopje, Nikos Chausidis Publisher, 2013. 
26. STOJADINOviK Sonja, "Macedonia beyond her Colorful Revolution: Who Were the Predecessors of the Movement?," in Gazela Pudar Draško et al. (eds), Democratic Engagement in South East Europe: Stories to be Told, Belgrade, Institute for Philosophy and Social Theory, 2018, p. 50-58.

27. During this research the author realized that the websites of the numerous and most popular groups and movements have simply disappeared. Even some media articles are not available any more.

28. Among many similar cases, one could point out the political attendance of leading SDSM members at all events and marches organized by NGO groups or activists, such as Freedom Square event (April 2009) or protests against police brutality in June 2011.

29. The paradox of counter-protests organized by the ruling VMRO-DPMNE had a long history, starting from the counter-student protests in 2009, and later on. The idea was to show that "people/citizens" spontaneously support the government in contrast to the "other people" that belonged to the SDSM. The result was that any protest movement would lose meaning because participation would appear unreliable and inauthentic.

30. See: PETKOVSKI Ljupco, The Political Culture, Europeanization and Fears in Macedonia. 2014 Report from the Survey Research "Eurometer," Skopje, Macedonian Centre for European Training, 2014.

31. Petrović Marko, "Rastko Mocnik: Ljudi u Srbiji su presiromašni da bi se bunili," [Rastko Mocnik: The People in Serbia Are too Impoverished to Protest], Blic, 20 April 2013, online: http:// www.blic.rs/Vesti/Politika/378677/Rastko-Mocnik-Ljudi-u-Srbiji-su-presiromasni-da-bi-sebunili (accessed in May 2019).

32. The reforms reportedly meant that state-supervised exams would be imposed on all students enrolled at state universities during and before completion of their first cycle of studies. It meant that professors' evaluation of their students would need to be eventually verified by state bureaucrats.

33. The website of the magazine Kozanostra is now inactive. The original link http:// www.kozanostra.net/masovni-studentski-protesti-vo-skopje-iljadnitsi-na-ulitsite/ was accessed on 10 October 2015.

34. Article available online: https://www.theguardian.com/world/2015/may/13/macedonialipstick-protester-jasmina-golubovska (accessed in May 2020).

35. "Macedonia's Maidan Moment," RFE/RLIVE, 21 May 2015.

36. The peak of the 2014 Ukrainian Revolution took place on the main square in Kiev, Maidan. The event got known as Euromaidan in reference to the alleged pro-EU orientation of the opposition that toppled the president and the government. SDSM had also been threatening Gruevski that he would end like Arab dictators. His first name Nikola was also spelled as Nikolae (to refer to the fate of Romania's Nicolae Ceauşescu). The rhetoric was for dramatization purposes, and served for mobilization especially after "Black Monday" in December 2012 (see note 22$)$.

37. BLAŽEVSKA Katerina, "Studentite na državen test - za nepartiski studentski protest" [Students on a state test - for non-party student protest], Deutsche Welle in Macedonian, 9 December 2014, online: https://frama.link/fY3A_4UZ (accessed in May 2020).

38. Some of the observations and citations are taken from the direct talks I had with the adult citizens who, like me, spontaneously joined the student marches.

39. The independent student organization Free Index had been active for a few years. It was the first to challenge the formal student organizations as not-representative, ineffective and politicized. It managed to raise some attention for the most urgent student concerns, but also criticized the politicization of the university, the diminishing of university autonomy and the desecularization of higher education. Its organization was also established on an exclusively horizontal principle and with no leadership. It failed to mobilize a wider student population, but after they graduated, its activists continued to be engaged in smaller circles of anarchist, leftist and social movements. 
40. The universities' leaderships were the last to respond to the government's measures for curbing autonomy; the official press release was issued in late December, at the time when the professors had already organized their plenum.

41. Today many of them are well-situated in the establishment as government advisers, spokespersons, associates at international organizations' offices, etc.

42. Open Letter, online : https://okno.mk/node/43413 (accessed in May 2020).

43. Open Letter, online : https://www.newappsblog.com/2014/12/an-open-letter-concerningthe-autonomy-of-macedonian-universities.html (accessed in May 2020).

44. "Državniot ispit so golema poddrška od profesorite - na inicijativata potpišani 200 profesori" [The State Exam with Great Support from the Professors - The Initiative is Signed by 200 Professors], Press24, 30 December 2014, online: https://www.press24.mk/drzhavniot-ispit-sogolema-poddrshka-od-profesorite-na-inicijativata-potpishanii-200-profesori (accessed in May 2020).

45. See: "Rally for the Freedom for Journalist Tomislav Kežarovski," Skopje, 20 January 2015, online: https://www.youtube.com/watch?v=cVPrM75g0Cw (accessed in May 2020).

46. The free zone was a staged performance. The protesters were going back and forth to their homes, taking a rest or shower, while fewer and fewer were present in the zone. That situation was registered by the university chancellor during his unexpected visit to the zone: he could not find a single student in the late afternoon hours. Similar testimonies came from many other members of the academic community.

47. PULJEK-SHANK Randal, FRITSCH Felix, “Activism in Bosnia-Herzegovina: Struggles against Dual Hegemony and the Emergence of 'Local First," East European Politics and Societies: and Cultures, vol. $33, \mathrm{n}^{\circ} 1,2019$, p. 135-156.

48. A 20-year-old Martin Neškovski was killed by an ununiformed policeman during a victory rally for the ruling VMRO-DPMNE following the success of early elections in June 2011. His death provoked mass protests.

49. "More than 1,500 Citizens at the Protest 'Justice for Martin, Freedom for All," Meta, 6 June 2015, online: https://meta.mk/en/poveke-od-1-500-gragani-na-protestot-pravda-za-martinsloboda-za-site/ (accessed in May 2020).

50. On the chronology (illustrated with photos) and the transformation of plenums into protest movement(s), see: GEORGIEVSKI Boris, “КАКО \#ПРОТЕСТИРАM ПРЕРАСНА ВО \#ШАРЕНАРЕВОЛУЦИЈА" [How \#I Protest Grew up into \#Colorful Revolution], Deutsche Welle in Macedonian, 28 April 2016, online: https://frama.link/_bxGc4FL (accessed in May 2020).

51. The intellectuals who did not take a side were labelled "relativist" (relativizator) as a pejorative term. This attitude spilled over into the pro-opposition media. A vociferous newspaper editor attacked a TV editor who stuck to principles of professional journalism and gave an opportunity to each side to speak: "A medium cannot have a consistent editorial line and public impact with the politics such as 'two minutes for Hitler, two minutes for the Jews"'. GEROSKI Branko, "Kurnaz Atanas" [Crafty Atanas], Sloboden pečat, 31 May 2015).

52. The following video presentation gives an overview of the protest actions in a time span of several years, i.e. since 2011 and even before, but it refers to \#IProtest as an agent of all these events: https://www.youtube.com/watch?v=X4Kpm9t4TwQ (accessed in May 2020). The video production is made by MOF, an NGO funded by Western donors, and leading staff from which (e.g. Bojan Maričić and Marjan Zabrčanec) later provided PR service to or joined the advisory team of Prime Minister Zoran Zaev.

53. The website of \#Protestiram is inactive so the whole archive has been lost (http:// protestiram.info). One could check the FB page (https://www.facebook.com/ protestiramezaedno/) and the Twitter account (https://twitter.com/protestiram). 
54. "Non-Partisan Coalition Partnership for Democratic Macedonia Formed," Meta, 8 May 2015, online: https://meta.mk/en/formirana-natpartiska-koalitsija-partnerstva-za-demokratskamakedonija/ (accessed in May 2020)

55. MonTAGE James, “Bombs over Skopje,” Politico, 22 May 2015, online: https://www.politico.eu/ article/bombs-over-skopje/ (accessed in May 2020).

56. A popular song of the Serbian band Bajaga and instruktori, "Pada vlada," online: https:// www.youtube.com/watch?v=d2IIrlhMLYI (accessed in May 2020).

57. JORDANOVSKA Meri, "Kontra-kamperite ostanuvaat pred Sobranie" [Counter-Campers Remain in Front of the Parliament], Prizma, 19 June 2015, online: https://prizma.mk/kontra-kamperiteostanuvaat-pred-sobranie/ (accessed in May 2020).

58. For instance, a poster of Che Guevara was displayed next to the US flag.

59. TV debate, 29 May 2015, online: https://novatv.mk/vangeli-vs-shilegov-koi-se-scenarijata-zaizlez-od-krizata/ (accessed in May 2020).

60. ŠIšovsKI Jordan, "David versus Goliath," online: http://zasedan.ie.mk/?p=1207 (accessed in May 2020).

61. The agreement's name refers to the residential area in Skopje in which the EU embassy is located and where the negotiations took place, in addition to a few sessions held in Strasbourg and Brussels.

62. See: "Commission Hammers out Macedonia Compromise," Euroactiv, 16 June 2015, online: https://www.euractiv.com/section/enlargement/news/commission-hammers-out-macedoniacompromise/_(accessed in May 2020).

63. Early in the student protests, the most exposed activists were invited to the US Embassy. According to one of them, the US officials asked if they were radical leftists or communists. The student activist responded that the participants of the 2015 protests held different political views, and what brought them together was the joint critique of the regime. For instance, he said that he was pro-NATO, but against Macedonia's membership to the EU. See Alex Sakalis's interview with David Stefanovski, "Macedonia's Long Year: Scandal, Protest and Revolution in the Balkans," Open Democracy, 18 June 2015, online: https://www.opendemocracy.net/en/caneurope-make-it/macedonias-long-year-scandal-protest-and-revolutio/ (accessed in May 2020).

64. VANGELI Atanas, "Pregovorite što bolat" [The Negotiations that Hurt], Focus Magazin, 12 June 2015, online: http://fokus.mk/pregovorite-shto-bolat/ (accessed in May 2020).

65. ŠIšovsKI, "David versus Goliath," op. cit.

66. A witty aphorism read: "We are neither VMRO-DPMNE nor SDSM, we are (from) Internet!"

67. LANE, “'Coloured Revolution' as a Political Phenomenon,” op.cit., p. 114.

68. The text is available online: http://eeas.europa.eu/archives/delegations/ the_former_yugoslav_republic_of_macedonia/press_corner/all_news/news/

2016/2016-07-20_agreement_en.htm (accessed in May 2019).

69. The same picture could be seen with respect to the external meddling of the EU and USA. See: "What Kind of Situation Is this?," Institute for Democracy "Societas Civilis" (IDSCS), Skopje, 2016, online: https://idscs.org.mk/en/portfolio/what-kind-of-situation-is-this/ (accessed in May 2020).

70. Actually the Macedonian version of Deutsche Welle coined the name of "Colorful Revolution" in an article of 19 April 2016. See a range of thematic articles entitled "Šarena revolucija," DW, 15 November 2018, online: https://frama.link/zt80gsjM (accessed in May 2020).

71. The Open Society Institute (Soros) Macedonia had already translated, published and disseminated the seminal books of Gene Sharp and Saul Alinsky on the eve of the 2014 student protests. This fact was revealed a bit later and shed a different light on the apparently selforganized and authentic student protests. Some of the participants confessed that they had received a certain amount of financial support from the institute at the very start of the protests. 
72. RoY Arundathi, “The NGO-ization of Resistance," online: https://beautifulrising.org/tool/thengo-ization-of-resistance (accessed in May 2020).

73. LANDRY Tristan, "The Colour Revolutions in the Rearview Mirror: Closer than they Appear," Canadian Slavonic Papers/Revue canadienne des slavistes, vol. 53, nº 1 (March) 2011, p. 1-24 (4).

74. The graphic designs can be seen online: http://sharena-revolucija.ie.mk/\#/ (accessed in May 2020).

75. Von Flottau Renate et al., "Die Revolutions-GmBH," Der Spiegel, 14 November 2005, online: https://www.spiegel.de/spiegel/print/d-43103188.html (accessed in May 2020).

76. BEISSINGER Mark, "Debating the Color Revolutions: An Interrelated Wave," Journal of Democracy, vol. 20, nº 1 (January), 2009, p. 74-77.

77. Not only because of geographic and political proximity, but the protesters had established good relationships with the members of the former "Otpor" from Serbia, who had been discretely assisting the process. Also the rhetoric against the regime resembled the one from the Arab Spring and other similar events. The organizers tried to create an image of a global solidarity through engaging a part of the Macedonian diaspora and through the creation of short videomessages showing young people from all over the world giving their support.

78. For the purpose of this research, the author tried to interview a number of the most eminent participants of the CR but just a few responded. They confirmed US and EU direct involvement in building the network and providing other logistics for the student and protest movements.

79. DeLISo Chris, “Europe's Macedonian Intervention," Balkananalysis, 13 June 2016, online: http:// www.balkanalysis.com/macedonia/2016/06/13/europes-macedonian-intervention-part-1assessing-eu-behavior/ (accessed in May 2020).

80. It is hard to offer solid proof of foreign financial support but the impresums of (already closed down) websites and TV talk shows, satirical programs, etc. indicate that support was coming from the West, through organizations such as USAID, NDI, British Council and the Soros Foundation.

81. WAY Lucan Ahmad, "The Real Causes of the Color Revolutions," Journal of Democracy, vol. 19, $\mathrm{n}^{\circ} 3$ (July) 2008, p. 55-69 (62).

82. CHETERIAN, "From Reform and Transition to "Coloured Revolutions," op. cit.

83. See results online: https://www.sobranie.mk/election-results-2016.nspx (accessed in May 2020)

84. The most serious scandal related to a misuse of the "audio bombs" for racketeering and infringement of justice involves the Special Prosecutor, Katica Janeva, and TV channel owner Bojan Jovanovski. The trial is in progress but the public has a déjà vu feeling: one regime replaces another, and except for the switch between VMRO-DPMNE and SDSM (and their respective leaders) literally nothing has changed. See: Lukić Filip, "The Fallen Anti-Corruption Heroine Katica Janeva," European Western Balkans, 3 September 2019, online: https:// europeanwesternbalkans.com/2019/09/03/the-fallenanti-corruption-heroine-katica-janeva/ (accessed in May 2020).

85. VANKovsKa Biljana, "Geopolitics of the Prespa Agreement: Background and After-Effects," Journal of Balkan and Near Eastern Studies, vol. 22, n 3, 2020, p. 343-371.

86. Leontopoulos Nikolas, "Who's Been Meddling in Macedonia? Not only Who You Think," Investigate Europe, online: https://www.investigate-europe.eu/whos-been-meddling-inmacedonia-not-only-who-you-think/ (accessed in May 2019); MARUŠIć Siniša Jakov, "Macedonia's Regime Change Boosts NATO Accession Hopes," Balkaninsight, 2 June 2017, online: https:// balkaninsight.com/2017/06/02/macedonia-boosts-its-nato-accession-hopes-05-31-2017/ (accessed in May 2020).

87. VANGeli Atanas, "Macedonia Political Briefing: Understanding the Regime Change in Macedonia in 2017 and its Consequences," China-CEE Institute Brief, 12 March 2018, online: https:// 
china-cee.eu/2018/03/12/macedonia-political-briefing-understanding-the-regime-change-inmacedonia-in-2017-and-its-consequences/ (accessed in May 2020).

88. "Tapes Show Zaev Discuss how he Abused the 2015 Wiretaps, his Influence over the Special Prosecutor and over the Soros Funded Protest Groups," Republika, 9 May 2020, online: https:// english.republika.mk/news/macedonia/tapes-show-zaev-discuss-how-he-abused-the-2015wiretaps-his-influence-over-the-special-prosecutor-and-over-the-soros-funded-protest-groups/ (accessed in May 2020).

89. Interview with Chantal Mouffe, "Transforming Political Consciousness," Green European Project, July 2015, online: http://www.greeneuropeanjournal.eu/wp-content/uploads/2015/09/ GEF-ED-2015-web.pdf (accessed in May 2020)

90. CHANDLER David, Empire in Denial. The Politics of State-Building, London, Pluto Press, 2006.

\section{ABSTRACTS}

This article analyzes the social movements that took place between 2014 and 2016 in Macedonia. These events got widely known because of the 2016 final performance: the so-called Colorful Revolution. However, their background, the main internal and international actors involved and their after-effects remain subject to highly conflicting and underexplored explanations. The main hypothesis of this article is that, in spite of its apparent authenticity as a grassroots social movement, the Colorful Revolution was closer to what has been called a "template revolution" or "colored revolution" and has already been seen in other parts of the world. This study draws mostly on primary sources associated with the personal involvement of the author in the protests. It aims to contribute to a better understanding of events which still polarize political and public discourse as well as social praxis in the country.

Cet article analyse les mouvements sociaux qui ont eu lieu entre 2014 et 2016 en Macédoine. Ces événements sont devenus célèbres en raison de la performance finale réalisée en 2016, appelée la Révolution des couleurs. Cependant, le contexte, les principaux acteurs internes et internationaux engagés et les répercussions font encore l'objet d'explications très contradictoires et sous-étudiées. L'hypothèse principale de cet article est que, malgré l'apparente authenticité d'un mouvement social issu de la base, la Révolution des couleurs a été plus proche de ce que l'on a appelé une "révolution sur modèle » ou une " révolution colorée » déjà observée dans d'autres parties du monde. L'étude s'appuie principalement sur des sources primaires liées à l'implication personnelle de l'auteure dans les manifestations. Elle vise à contribuer à une meilleure compréhension des événements qui polarisent encore le discours politique et public ainsi que la praxis sociétale dans le pays.

\section{INDEX}

Mots-clés: Macédoine, mouvement social, protestation, communauté internationale

Keywords: Macedonia, social movement, protest, international community

Geographical index: Macédoine 


\section{AUTHOR}

\section{BILJANA VANKOVSKA}

Ss. Cyril and Methodius University, Skopje bvankovska[at]gmail.com 